\title{
Optimizing Jigsaw Type of Cooperative Learning Model to Improve Students' Mathematical Self- Confidence
}

\section{Muhamad Ikhsan Sahal Guntur ${ }^{*}$, Seftika Anggraini², Raden Rosnawati $^{3}$}

1,3 Mathematics Education, Graduate School, Yogyakarta State University, Yogyakarta

2 SMA Negeri 1 Ngemplak, Sleman, D.I. Yogyakarta

*email: muhamadikhsan.2018@student.uny.ac.id

\begin{abstract}
Abstrak
Penelitian ini dilatar belakangi oleh rendahnya kepercayaan diri siswa dalam proses pembelajaran di SMAN 1 Ngemplak dimana siswa yang menjadi responden adalah 35 siswa yang terdiri dari 22 siswa perempuan dan 13 laki-laki. Solusi yang diberikan adalah menggunakan model pembelajaran cooperative learning tipe jigsaw. Berdasarkan evaluasi siklus I diperoleh nilai rata-rata 61,71 dengan persentase ketuntasan belajar $57 \%$. Skor tertinggi yang diperoleh siswa adalah 80 dan skor terendah adalah 40 . Sedangkan skor kepercayaan diri pada pra siklus adalah 66,63 yang berada pada kategori sedang. Setelah dilakukan siklus I, skor kepercayaan diri meningkat menjadi 80,17 tetapi masih dalam kategori sedang. Berdasarkan hasil evaluasi siklus II, diperoleh nilai rata-rata 75,57 yang sebelumnya adalah 61,71. Ketuntasan belajar pada akhir siklus II adalah 89\% yang meningkat dari 57\% pada akhir siklus I. Selain itu, peningkatan kepercayaan diri siswa juga terlihat dari perbandingan hasil angket penilaian pada pra siklus, siklus I dan siklus II, yang awalnya 66,63 menjadi 80,17 dan berakhir 86,80 .
\end{abstract}

Kata Kunci: Kepercayaan diri; Cooperative Learning; Jigsaw

\begin{abstract}
This research is motivated by the low self-confidence of students in the learning process at SMAN 1 Ngemplak where the students who were respondents were 35 students consisting of 22 female students and 13 male. The solution given is using a cooperative learning model with jigsaw type. Based on the evaluation of cycle I obtained an average value of 61.71 with a percentage of mastery learning $57 \%$. The highest score obtained by students is 80 and the lowest score is 40 . Whereas for giving a confidence questionnaire in pre-cycle is 66.63 in the medium category and after cycle I it increases to 80.17 but still in the medium category. The results obtained in the first cycle are still quite good or have not been fulfilled. Based on the results of the second cycle evaluation, the average is obtained 75.57 and $89 \%$ completeness learning increased from $57 \%$ previously. In addition, an increase in student confidence was also seen from the comparison of the results of the assessment questionnaire in pre-cycle, cycle I and cycle II, which initially 66.63 became 80.17 and ended 86.80 .
\end{abstract}

Keywords: Confidence; Cooperative Learning; Jigsaw

\section{BACKGROUND}

Education is a social process where a person is influenced by an environment so they can develop the potential that they have. According to the Law of the Republic of Indonesia Number 20 Year 2003 Article 1 paragraph (1) that education is a conscious and planned effort to create an atmosphere of learning and learning process so that students actively develop their potential to have spiritual spiritual strength, self-control, personality, 
intelligence, noble morals, as well as the skills needed by himself, society, nation and state (Kemenristekdikti, 2003). In this connection, mathematics education can also be used as an effort to realize these goals (Guntur, 2015).

Mathematical learning aims to develop abilities and shape the student's personality through the learning process (Valero, 2001). The purpose of learning mathematics is very closely related to student learning outcomes in the cognitive and affective domains. The cognitive domains include understanding, problem solving, communication, reasoning, and so on. While the affective domain includes attitudes, motivations, independence, interests, self-confidence of students and so on (Daniela, 2015).

Based on the results of a preliminary study of students' confidence in mathematics conducted by the author in one of the four X classes at SMAN 1 Ngemplak on Monday, November 1, 2019, showed that out of 35 students, students who reached the medium criteria were 16 people while students who reached the low criteria were 19 people. It appears that there are no students who reach very high criteria and there are still many students who are at low criteria. the results of observations made by researchers showed that the ability of students to understand mathematics is still lacking and there is no discussion between students.

Whereas the role of students' self-confidence is so much in learning even in daily life. With this self-confidence, students have the ability to take appropriate and effective actions in a variety of situations, despite challenges both from themselves and from others (Burton $\&$ Platts, 2006). According to Mulyasa (2016), self-confidence is a positive feeling that can be used as initial capital in a life, which will encourage success or failure in someone doing something.

One of the learning models that is in accordance with the above problems and also in accordance with the curriculum in force today is jigsaw cooperative learning or cooperative learning type jigsaw (Rezende et al., 2017). According to Kusuma (2018), the Jigsaw cooperative learning model is a cooperative learning model by means of students learning in small groups of four to six people heterogeneously, and students collaborating positive interdependence and independently responsible. Researchers argue that this type of jigsaw cooperative learning will be able to solve existing problems in order to increase self-confidence in students. Because this learning has the advantage of being able to develop the ability of students to express ideas and ideas without fear of being wrong, students can be more active in talking, improve social relationships, and of course can develop self-confidence.

Based on the explanation above, the researcher tries to conduct research that is expected to be able to optimize the learning model of learning to improve students' mathematical confidence in high school logarithm material. 


\section{METHOD}

This type of research is the Classroom Action Research (CAR) conducted in collaboration between the principal, mathematics teacher and researcher. Class action research according to Sutama (2010: 15-21) is an effort to improve learning practices to be effective. The stages in this research model include: Planning, implementing actions, observing, reflecting, improving planning, implementing actions, observing, reflecting.

This research was conducted at a senior high school in Yogyakarta. The study was conducted for 6 weeks in October to November 2019. Students who were the subject were students of class X.b. The number of students in class X.b is 35 people consisting of 22 female and 13 male students. Data collection techniques in this study through interviews, observation, documentation, questionnaires and tests: 1) interviews are used as initial communication to obtain the information needed, 2) observation is used to plan the next action, 3) documentation to support and increase trust and proof a problem, 4) Questionnaire to measure the affective object under study, 5) test to measure the ability of learning outcomes of the object under study (Arikunto, 2008). The questionnaire used in this study is a questionnaire developed by Dianita (2018) in her thesis. Validation score is 0.926 which is above 0.6 which means the questionnaire is ready to use (Dianita, 2018).

Data analysis techniques in this study were through comparative techniques and critical techniques. Comparative techniques use quantitative data obtained from test results and questionnaires. then processed using a percentage description. Critical techniques use qualitative data obtained from observations (Sutama, 2011). As a basis for describing the success of Jigsaw's cooperative learning model, which is characterized by increased confidence and learning outcomes in mathematics and the implementation of all stages of jigsaw learning. The validity of the data that has been collected and recorded in research activities is selected and determined by triangulation. Triangulation in data collection techniques combines various existing data collection techniques and data sources. When a researcher collects data by triangulation, the researcher actually collects data which at the same time tests the validity of the data, that is checking the credibility of the data with various data collection techniques and various sources (Sugiyono, 2008). The scale of 5 used to categorize the results of the questionnaire into each category that can be seen in Table 1.

Table 1. Scale Assessment Criteria 5

\begin{tabular}{ccc}
\hline No & Interval & Criteria \\
\hline 1 & $X>105$ & Very good \\
2 & $85<X \leq 105$ & Good \\
3 & $65<X \leq 85$ & Good enough \\
4 & $45<X \leq 65$ & Poor \\
5 & $X \leq 45$ & Not good \\
\hline
\end{tabular}




\section{RESULTS AND DISCUSSION}

\subsection{Cycle I research result}

Learning in cycle I took place in three meetings. The first meeting lasted for 45 minutes which was filled with re-introduction of the basic concepts of logarithms. The second meeting lasted $2 \times 45$ minutes filled with the introduction of 5 properties of the logarithmic equation. The third meeting lasted for 45 minutes where at this meeting an evaluation was carried out in the form of a post test and the giving of a questionnaire to students. The material discussed in cycle I includes logarithmic equations in which five equations are introduced. Based on the observation sheet and discussion with the teacher, there are some shortcomings and things that support the implementation of the learning cycle scenario I.

As for the deficiencies in the learning process based on the observation sheet, in the form of: (1) In the first meeting to the second meeting of the first cycle, the teacher skips learning motivation activities; (2) the use of time allocation is not good so some learning activities are not carried out; (3) the implementation of presentations not maximum because most students still refuse to present their answers; (4) some students do not listen and pay attention to the explanations of the teacher and his friends; and (5) the teacher's guiding activities tend to focus on just one group so that other groups who have difficulty getting a rather long response in obtaining guidance.

After learning in the first cycle is complete, the teacher evaluates and gives the student self-confidence questionnaire. Based on observations and discussions with observers, deficiencies contained in the first cycle will be corrected in the second cycle, i.e. (1) In the next cycle the teacher should provide learning motivation to students so that students are enthusiastic to learn; (2) plan more effective time allocation, and allocate time to deliver material must be efficient; (3) optimize classroom management, especially when discussing; (4) invite students to be more enthusiastic in presenting the results of group discussions; and (5) the teacher is more focused on other groups and not just focused on one group.

\subsection{Cycle II research result}

Learning in cycle II takes place in three meetings. The first meeting lasted for 45 minutes filled with learning inequality logarithms. The second meeting lasted 2 x 45 minutes in which there were steps in learning jigsaw and also evaluating the deficiencies of the first cycle. The third meeting lasted for 45 minutes in the form of evaluating the provision of post-tests and self-confidence questionnaires again. Based on the observations of researchers, the results of observations and discussions with observers, in the second cycle the learning process has been going according to the scenario. The results of the 
evaluation will depend on each individual. The results of the confidence questionnaire from pre-cycle, cycle I and cycle II are in the following Figure 1.

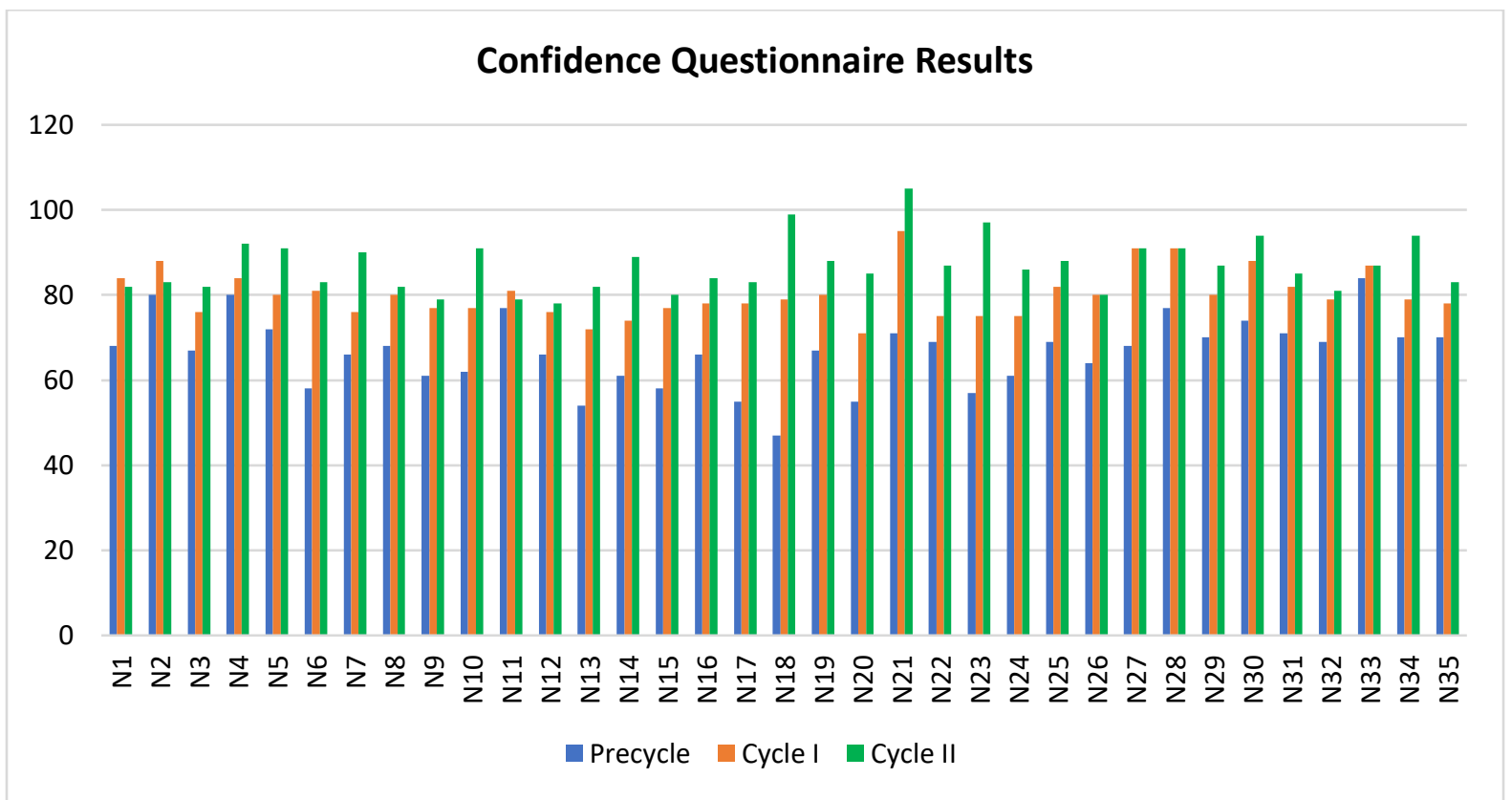

Figure 1. Confidence Questionnaire Results

The results of the student self-confidence questionnaire when categorized into each criterion will show differences between cycles based on each category as shown in Table 2 .

Table 2. Percentage of Each Category

\begin{tabular}{lrrr}
\hline \multicolumn{1}{c}{ Criteria } & Pre-cycle & Cycle I & Cycle II \\
\hline Very good & $0 \%$ & $0 \%$ & $0 \%$ \\
Good & $0 \%$ & $17.65 \%$ & $52.94 \%$ \\
Good enough & $64.71 \%$ & $85.29 \%$ & $44.12 \%$ \\
Poor & $35.29 \%$ & $0 \%$ & $0 \%$ \\
Not good & $0 \%$ & $0 \%$ & $0 \%$ \\
\hline
\end{tabular}

However, if the confidence questionnaire data is displayed based on the average of each cycle, the difference will be more noticeable, as in Table 3. Where the change in the average questionnaire results seems to equal the increase from the 66.63 in the good enough category on pre-cycle to 80.17 in the good enough category on the first cycle and last up to 86.80 in the second cycle in the good category. 
Table 3. Mean Results for The Questionnaire

\begin{tabular}{lll}
\hline \multicolumn{1}{c}{ Cycle } & \multicolumn{1}{c}{ Mean } & \multicolumn{1}{c}{ Criteria } \\
\hline Pre-cycle & 66.63 & Good enough \\
Cycle I & 80.17 & Good enough \\
Cycle II & 86.80 & Good \\
\hline
\end{tabular}

Based on the learning done thoroughly in cycle I and cycle II in class X. with the application of the jigsaw method, there is also an increase in student learning outcomes in mathematics learning. The increase occurred in accordance with the indicators that have been used by researchers, namely students who passed the KKM (standard minimum) score. The data obtained by researchers about the results of learning mathematics in class X, starting from cycle I to cycle II are presented in the following Figure 2 .

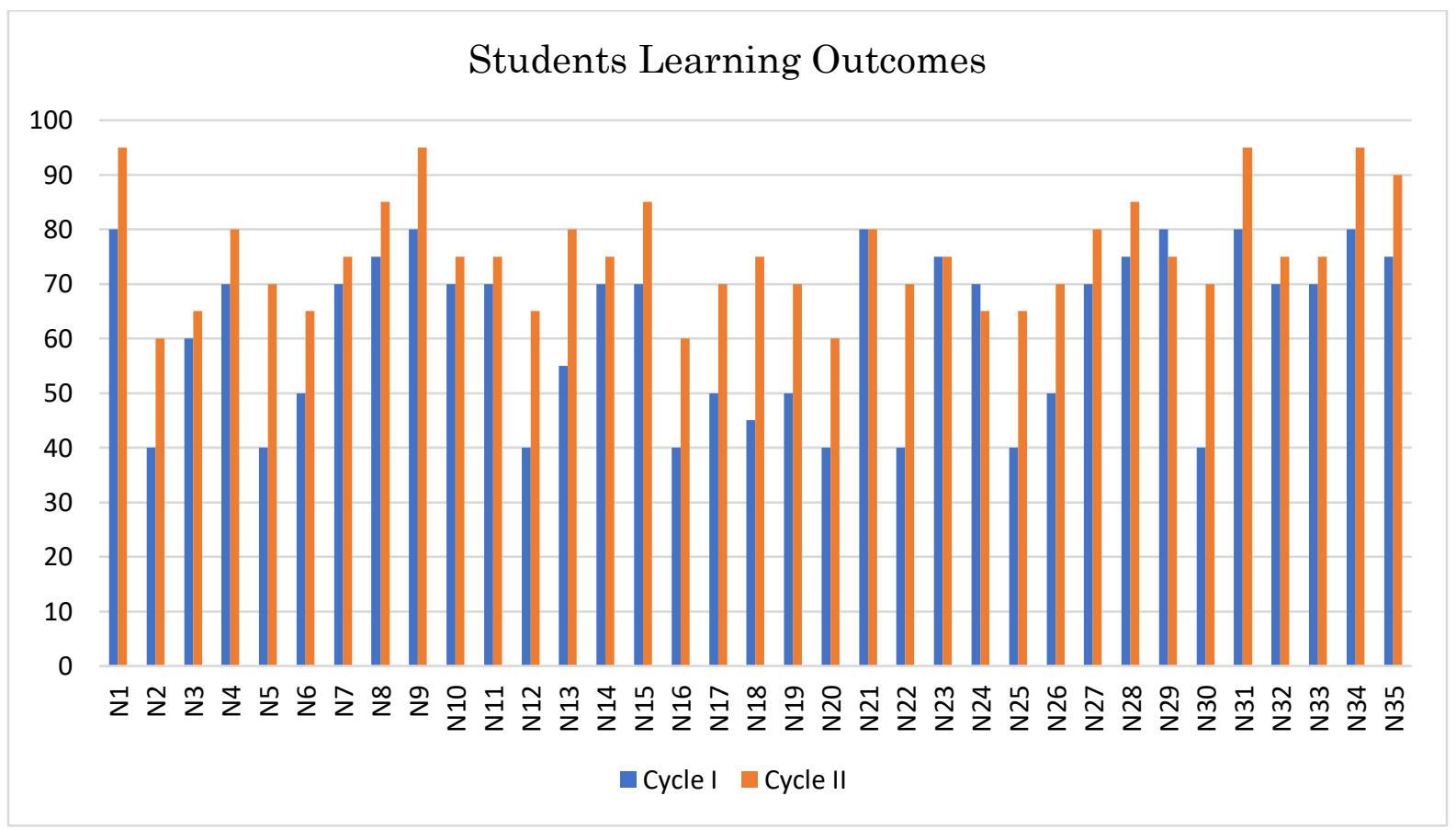

Figure 2. Students Learning Outcomes

When viewed as a whole, student learning outcomes have also increased on average can be seen in the following Table 4 .

Table 4. Average of Each Cycle

\begin{tabular}{lll}
\hline \multicolumn{1}{c}{ Cycle } & \multicolumn{1}{c}{ Average } & \multicolumn{1}{c}{ Completeness } \\
\hline Cycle I & 61.71 & $57 \%$ \\
\hline Cycle II & 75.57 & $89 \%$ \\
\hline
\end{tabular}




\subsection{Discussion}

This class action research was carried out as an effort to increase student confidence in mathematics subject matter of logarithms by applying jigsaw type cooperative learning. This research was conducted in two cycles based on time allocation, namely three meetings. Cycle I consisted of three meetings and cycle II consisted of three meetings, each cycle evaluating one meeting. The implementation of the first cycle for the first and second meetings are carried out based on the learning implementation plan that has been prepared in accordance with the stages of cooperative learning. After the learning of two meetings, an evaluation was conducted for the first cycle and the questionnaire was given to the students' confidence. Based on the evaluation of cycle I obtained an average grade of 61.71 with a percentage of mastery learning $57 \%$. The highest score obtained by students is 80 and the lowest score is 40 . While for giving self-confidence questionnaire in pre-cycle is 66.63 in the medium category and after cycle I it increased to 80.17 but still in the medium category. The results obtained in the first cycle are still quite good or have not met the performance targets in this study. This is caused by several factors, namely as follows. In the first meeting to the second meeting of the first cycle, the teacher skips learning motivation activities. the two teachers have not been maximal in conveying the Relating stages, namely conveying material concepts and connecting the material being studied with the material that has been learned.

The use of time allocation is not good so some learning activities are not carried out properly. The implementation of group presentations is less than optimal and it is still difficult to pay attention to the group being presented. Some students do not listen and pay attention to the teacher's explanation. At the first meeting until the second meeting of the first cycle, the teacher's guiding activities tend to focus on just one group so that other groups who have difficulty getting a rather long response in obtaining guidance. Researchers reflect based on the shortcomings in the first cycle above, by planning the following actions.

The teacher prioritizes the mastery of the class and motivates students to discuss more enthusiastically than before, especially when the percentage of group discussion results. In the next cycle the teacher should provide learning motivation to students so that students are enthusiastic to learn. Planning a more effective time allocation, and allocating time to deliver material must be added. Optimizing class management, especially when discussing.

The teacher activates questions and answers with students when giving an apperception. Invite students to make conclusions from the material being studied. the teacher is more focused on other groups and not just focused on one group. The learning process in cycle II is carried out like cycle I, but the teacher makes improvements based on the deficiencies found in cycle I. Based on the results of the second cycle evaluation the average value of 


\section{Mandalika Mathematics and Education Journal \\ Volume 2 Nomor 2, Desember 2020 e-ISSN 2715-1190 | | p-ISSN 2715-8292 \\ DOI: http://dx.doi.org/10.29303/jm.v2i2.1773}

75.57 was obtained which previously was 61.71 with $89 \%$ learning completeness increasing from the previous $57 \%$. The increase in completeness is due to 35 students only 3 students who scored less than the specified KKM, while the remaining 32 students scored above the KKM. As for giving questionnaires to students' confidence in cycle II. The increase in the average value and the percentage of completeness in the second cycle occurs because the implementation of learning using the cooperative learning model has been running in accordance with the plans that have been prepared. In addition, teachers are also able to minimize deficiencies in class mastery, so that the implementation of lesson plans can take place better than cycle I.

This shows that the time allocation can proceed as planned. Also seen an increase in the average value of the first cycle and second cycle that is equal to $13.85 \%$. In addition, the increase in students' confidence was also seen from the comparison of the scoring questionnaire results in pre-cycle I, cycle I and cycle II, which was initially 66.63 to 80.17 and then ended 86.80. An increase in the average value and confidence of students can be used as an indicator of research success so that in this study it is said to be successful. Therefore, it can be said that students' confidence in logarithmic material increases using the jigsaw type of cooperative learning model.

\section{CONCLUSION}

Jigsaw type of cooperative learning model can increase student confidence in senior high school. The results of this study are tested for schools where the respondent is located and cannot be generalized to other schools in a week. Further research is needed to find out the effectiveness of the jigsaw type of learning cooperative learning model to increase student confidence.

\section{REFERENCE}

Arikunto, S. (2008). Prosedur Penelitian Suatu Pendekatan Praktik. Rineka Karya.

Burton, K., \& Platts, B. (2006). Building confidence for dummies. West Sussex: John Wiley \& Sons, Ltd.

Daniela, P. (2015). The Relationship Between Self-Regulation, Motivation And Performance At Secondary School Students. Procedia - Social and Behavioral Sciences, 191, 2549-2553. https://doi.org/10.1016/j.sbspro.2015.04.410

Dianita, N. K. (2018). Pengaruh Keyakinan Siswa Tentang Matematika Terhadap kemampuan pemecahan masalah, Kemampuan berpikir kritis, dan kepercayaan diri Siswa Kelas VII di Kabupaten Sleman. Universitas Negeri Yogyakarta.

Guntur, M. I. S. (2015). Persepsi guru matematika SMA di Kayuagung terhadap Kurikulum 2013. Jurnal Pendidikan Matematika, 9(pendidikan matematika), 68-77. https://doi.org/10.22342/jpm.9.1.2134.68 - 77

Kemenristekdikti. (2003). Undang-undang Republik Indonesia Nomor 20 Tahun 2003.

Kusuma, A. (2018). Meningkatkan Kerjasama Siswa dengan Metode Jigsaw. Konselor, 7. https://doi.org/10.24036/02018718458-0-00

Mulyasa, E. (2016). Pengembangan dan Implementasi Kurikulum 2013. PT Remaja Rosdakarya. 
Mandalika Mathematics and Education Journal

Volume 2 Nomor 2, Desember 2020

e-ISSN 2715-1190 | | p-ISSN 2715-8292

DOI: http://dx.doi.org/10.29303/jm.v2i2.1773

Rezende, W. J., Albuquerque, E. S., \& Ambrosio, A. P. (2017). Use of Augmented Reality to Support Education - Creating a Mobile E-learning Tool and using it with an Inquiry-based Approach. Proceedings Ofthe 9th International Conference on Computer Supported Education, 1(Csedu), 100-107. https://doi.org/10.5220/0006318701000107

Sugiyono. (2008). Memahami Penelitian Kualitatif. Rineka Cipta.

Sutama. (2011). Penelitian Tindakan. Surya Offset.

Valero, P. (2001). Social justice and mathematics education gender, class, ethnicity and the politics of schooling. ZDM The International Journal for Mathematics Education, 33(6), 187-191. 